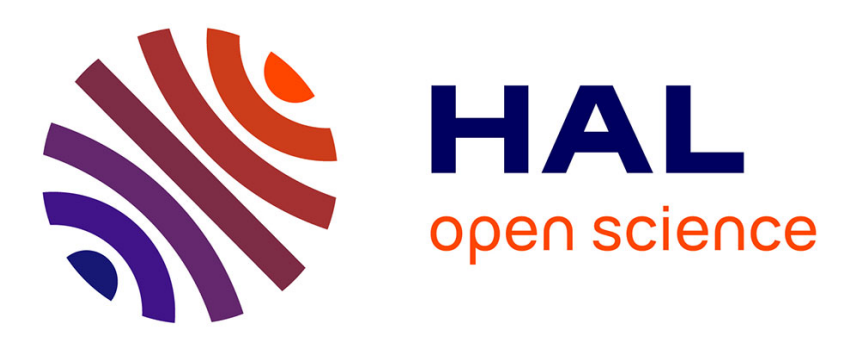

\title{
Oxidation behaviour of a hot isostatically pressed silicon nitride material
}

L. Themelin, M. Desmaison-Brut, M. Billy

\section{To cite this version:}

L. Themelin, M. Desmaison-Brut, M. Billy. Oxidation behaviour of a hot isostatically pressed silicon nitride material. Journal de Physique IV Proceedings, 1993, 03 (C9), pp.C9-C5-881-C9-C5-888. 10.1051/jp4:1993991 . jpa-00252433

\section{HAL Id: jpa-00252433 https://hal.science/jpa-00252433}

Submitted on 1 Jan 1993

HAL is a multi-disciplinary open access archive for the deposit and dissemination of scientific research documents, whether they are published or not. The documents may come from teaching and research institutions in France or abroad, or from public or private research centers.
L'archive ouverte pluridisciplinaire HAL, est destinée au dépôt et à la diffusion de documents scientifiques de niveau recherche, publiés ou non, émanant des établissements d'enseignement et de recherche français ou étrangers, des laboratoires publics ou privés. 


\title{
Oxidation behaviour of a hot isostatically pressed silicon nitride material
}

\author{
L. Themelin, M. Desmaison-Brut and M. Billy
}

Laboratoire de Céramiques Nouvelles, URA CNRS n ${ }^{\circ} 320,123$, Avenue Albert Thomas, 87060 Limoges Cedex France

\begin{abstract}
The oxidation behaviour of a dense silicon nitride material containing the minimum amount of additives was studied. A silicon nitride powder was hot isostatically pressed in the presence of $0.5 \mathrm{wt} \% \mathrm{Y}_{2} \mathrm{O}_{3}$ and $0.025 \mathrm{wt} \% \mathrm{Al}_{2} \mathrm{O}_{3}$. The dense material obtained was oxidized for 24 hours, in an oxygen atmosphere within the temperature range $1475-1650^{\circ} \mathrm{C}$. The high oxidation resistance of this material may be related to the low amount of sintering aid initially introduced and consequently to the composition of the grain boundary phase. According to the temperature, the apparent activation energies for the oxidation processes, ranged from 355 to $680 \mathrm{~kJ} / \mathrm{mole}$.
\end{abstract}

\section{Introduction.}

Dense silicon nitride (SN) materials are usually obtained by pressureless sintering or by hot pressing (HP). Additives, which are necessary to attain complete densification, are located after sintering at triple points and along grains boundaries. Hot isostatic pressing (HIP) is a technique which allows the production, at high temperature and pressure, of denser components by using the minimum quantity of sintering aids.

The high temperature behaviour of silicon nitride ceramics has been studied extensively $[1$, 2] and is mainly governed by the amount and nature of the intergranular phase confined between the grains. Among the various oxides used as densification aids $\left(\mathrm{MgO}, \mathrm{Al}_{2} \mathrm{O}_{3}, \mathrm{CeO}_{2}\right.$, $\mathrm{Y}_{2} \mathrm{O}_{3}, \mathrm{BeAl}_{2} \mathrm{O}_{4}$, etc...), yttrium oxide yields improved oxidation resistance in high temperature environments. The preferential use of yttria as a densification aid for $\mathrm{Si}_{3} \mathrm{~N}_{4}$ sintering results in the formation, at the grain boundaries, of a highly refractory secondary phase. Most studies to date indicate that the oxidation kinetics of hot pressed silicon nitrides are described by a parabolic dependence with time, which shows the diffusion nature of the oxidation process $[3,4]$.

G.E. Gazza [5] observed that a minimum amount of $5 \mathrm{wt} \% \mathrm{Y}_{2} \mathrm{O}_{3}$ was required to complete the formation of an oxynitride boundary phase producing dense material and leading to a significant improvement in high temperature properties. In the same way, G.Q. Weaver [6] noticed that below a critical $\mathrm{Y}_{2} \mathrm{O}_{3}$ content $(8 \mathrm{wt} \%)$, there was no degradation of properties. Improvements concern the flexural strength, the thermal shock and the oxidation resistance. In contrast, higher yttria content $(>11 \mathrm{wt} \%$ ) silicon nitride materials, when oxidized at $1100{ }^{\circ} \mathrm{C}$ for 100 hours, showed the expected degradation. On a commercially available HPSN doped with $7 \mathrm{wt} \%$ yttria, severe degradation in strength was observed between 600 and $1000{ }^{\circ} \mathrm{C}$, due to microcrack formation as a result of oxidation [7]. An $8 \mathrm{wt} \% \mathrm{Y}_{2} \mathrm{O}_{3}, 2 \mathrm{wt} \%$ $\mathrm{Al}_{2} \mathrm{O}_{3}$ HPSN showed instability at $800-1000{ }^{\circ} \mathrm{C}$, leading to a relatively small weight gain. At 
$1200^{\circ} \mathrm{C}$, the residual glass softening of the amorphous phase retarded or prevented microcrack formation. For higher concentrations of $\mathrm{Y}_{2} \mathrm{O}_{3}$, the continuous intergranular phase, which is viscous at high temperature, permitted inward and outward diffusion of reactants and additives species, leading to a gradient of depleted cations and the formation of $\mathrm{Si}_{2} \mathrm{~N}_{2} \mathrm{O}$. F.F. Lange [8] demonstrated that materials within the $\mathrm{Si}_{3} \mathrm{~N}_{4}-\mathrm{Si}_{2} \mathrm{ON}_{2}-\mathrm{Y}_{2} \mathrm{Si}_{2} \mathrm{O}_{7}$ triangle (Fig. 1) precluded the formation of unstable compounds and were extremely resistant to oxidation. This conclusion was confirmed by C.L. Quackenbush [9] who found it preferable - for optimal oxidation resistance - to maintain the $\mathrm{Y}_{2} \mathrm{O}_{3}-\mathrm{SiO}_{2}$ ratio in such a proportion that no $\mathrm{Y}_{2} \mathrm{Si}_{3} \mathrm{O}_{3} \mathrm{~N}_{4}$ formed. Between $900-1350{ }^{\circ} \mathrm{C}$, oxidation is believed to be controlled by oxygen diffusion through the surface silicate layer, but at $1350^{\circ} \mathrm{C}$, the surface oxide composition tends toward pure $\mathrm{SiO}_{2}$ and the oxidation rate decreases. Two silicon nitride billets, with both 4 and 8 wt $\% \mathrm{Y}_{2} \mathrm{O}_{3}$, have been oxidized in air, in the temperature range $700-1000{ }^{\circ} \mathrm{G}$ [10]. The first composition led to the formation of phases, which were within the compatibility triangle (Fig. 1) and so, was highly resistant at intermediate temperatures. On the other hand, the material sintered with $8 \mathrm{wt} \%$ yttria contained unstable $\mathrm{Y}_{5} \mathrm{~N}\left(\mathrm{SiO}_{4}\right)_{3}$ which was outside the triangle. This behaviour was also described by J.B. Veyret [11] in the temperature range $800-1400^{\circ} \mathrm{C}$ who proposed a model for the oxidation of a $9 \mathrm{wt} \%$ yttria HPSN, containing a crystalline grain boundary phase with apatite structure $\mathrm{Y}_{10}\left(\mathrm{SiO}_{4}\right)_{6} \mathrm{~N}_{2}$. At low temperature $\left(800-900^{\circ} \mathrm{C}\right)$ internal oxidation of the crystalline grain boundary phase occurs. The oxidation product: $\mathrm{Y}_{4.67}\left(\mathrm{SiO}_{4}\right)_{3} \mathrm{O}$, is not protective, so the reaction progresses toward the bulk by oxygen diffusion through the largest grain boundaries. At temperature higher than $900^{\circ} \mathrm{C}$, silica layer formation is dominant, the grain boundaries are closed and internal oxidation stops. Between 1400 and $1590^{\circ} \mathrm{C}$, precipitation of an intergranular phase appears, which is located between the outside compact scale and the core [12]. This phenomenon has a temporary stabilizing effect because it inhibits the outward diffusion of impurities, which may be rate limiting.

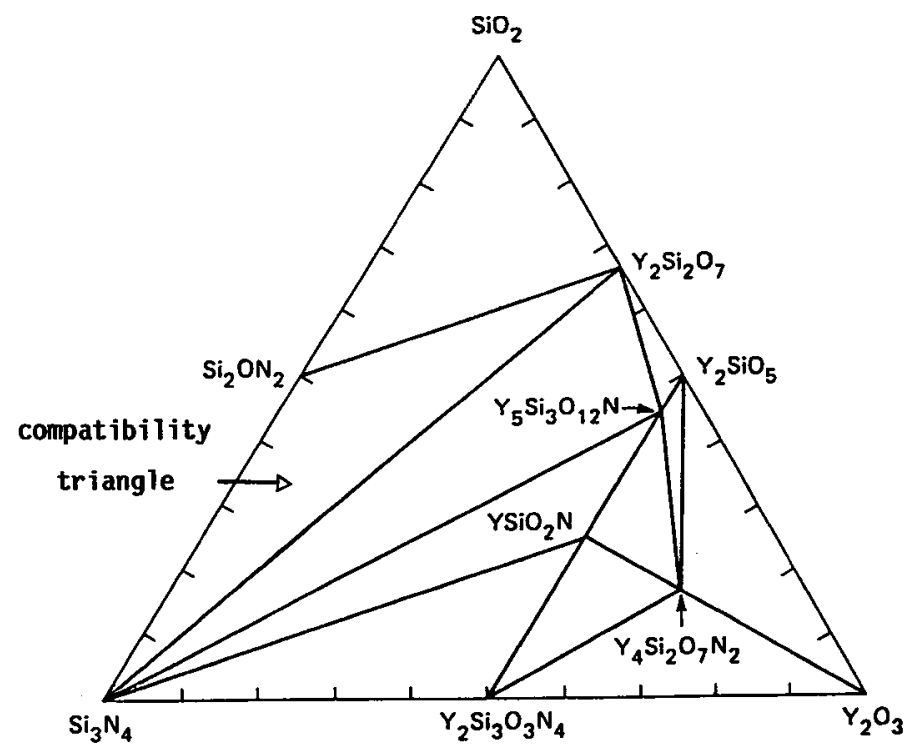

Fig. 1. - Phase relations in the $\mathrm{Si}_{3} \mathrm{~N}_{4}-\mathrm{SiO}_{2}-\mathrm{Y}_{2} \mathrm{O}_{3}$ system [1]. 
The literature demonstrates that the use of high pressures $(3000-7000 \mathrm{MPa})$ results in the formation of more highly resistant materials [13]. Hot isostatic pressing was applied as a post-treatment in order to complete the densification of silicon nitride ceramics having small amount of porosity $(<6 \%)$. This treatment permits pore filling, which is controlled by the viscosity and amount of the liquid phase and consequently improves the thermomechanical properties. RBSN samples, doped with 0.7 to $7 \mathrm{wt} \% \mathrm{Y}_{2} \mathrm{O}_{3}$, were post-hiped at $1750{ }^{\circ} \mathrm{C}$, $200 \mathrm{MPa}$ for $30 \mathrm{~min}$. [14]. On subsequent oxidation at $1350^{\circ} \mathrm{C}$, the lowest value of the parabolic oxidation rate constant occurred for the material with the lowest amount of $\mathrm{Y}_{2} \mathrm{O}_{3}$ aid. Parabolic kinetics were also recorded during oxidation, between 1100 and $1425^{\circ} \mathrm{G}$, of a sinter-hip silicon nitride containing $6 \mathrm{wt} \% \mathrm{Y}_{2} \mathrm{O}_{3}$ and $4 \mathrm{wt} \% \mathrm{Al}_{2} \mathrm{O}_{3}[15]$. The surface morphology of the oxide scale varied with temperature, composition and cooling rate. After rapid cooling, the main crystalline product was $\mathrm{SiO}_{2}$, while after slow cooling, crystals of $\mathrm{Y}_{2} \mathrm{Si}_{2} \mathrm{O}_{7}$ precipitated out. Data points suggest a change of behaviour at about $1400^{\circ} \mathrm{C}$. An equilibrium composition for the formation of $\mathrm{Y}_{2} \mathrm{Si}_{2} \mathrm{O}_{7}$ could be the explanation. Above $1400{ }^{\circ} \mathrm{C}$, the oxidation rate decreased by precipitation of the phase below the silica layer. The activation energy values derived were different below and above $1400^{\circ} \mathrm{C}$ i.e. 865 and $190 \mathrm{~kJ} / \mathrm{mole}$ respectively.

A typical pressureless sintered $\mathrm{Si}_{3} \mathrm{~N}_{4}$ based ceramic containing $5 \mathrm{wt} \% \mathrm{Y}_{2} \mathrm{O}_{3}$ and $2.5 \mathrm{wt} \%$ $\mathrm{Al}_{2} \mathrm{O}_{3}$, was subjected to hot isostatic pressing at $1700^{\circ} \mathrm{C}$ and $180 \mathrm{MPa}$ [16]. After hiping, the glassy pockets were reduced and the distribution of the secondary phases at grain boundaries was more regular. Oxidation was conducted in flowing oxygen from 1300 to $1500{ }^{\circ} \mathrm{C}$. Up to $1400{ }^{\circ} \mathrm{C}$, there was a minimization of the outward cationic (Al and $\mathrm{Y}$ ) diffusion compared to the starting nitride. At about $1400^{\circ} \mathrm{C}$, YAG crystallisation restrained the outward cationic migration and counterbalanced viscosity changes. This phenomenon again resulted in different apparent activation energies according to oxidation temperature $(800 \mathrm{~kJ} / \mathrm{mole}$ up to $1450{ }^{\circ} \mathrm{C}$ and $440 \mathrm{~kJ} /$ mole above $1450^{\circ} \mathrm{C}$ ). Nevertheless, up to $1450^{\circ} \mathrm{C}$, the hiped material was more resistant to oxidation than the non-treated one.

There is no lack of agreement between all these investigations, which clearly demonstrate that the oxidation of silicon nitride depends on the amount and composition of additives.

\section{Experimental.}

The silicon nitride powder was supplied by UBE Industries, Japan. The powder was homogeneous and consisted of submicronic spherical grains. The specific surface area was about $14 \mathrm{~m}^{2} / \mathrm{g}$. The average particle size was close to $0.6 \mu \mathrm{m}$. The grains composition is listed in table I.

Table I. - Chemical analysis of the starting powder (wt\%).

\begin{tabular}{|c|c|c|c|c|c|c|c|c|c|c|}
\hline $\mathrm{Si}$ & $\mathrm{N}$ & $\mathrm{O}$ & $\mathrm{Al}$ & $\mathrm{Ti}$ & $\mathrm{Fe}$ & $\mathrm{Ca}$ & $\mathrm{Mg}$ & $\mathrm{K}$ & $\mathrm{Na}$ & $\mathrm{G}$ \\
\hline 60 & 38 & 1.2 & 0.24 & 0.05 & 0.02 & 0.09 & 0.01 & 0.02 & 0.28 & 0.1 \\
\hline
\end{tabular}

X-ray diffraction analysis indicated that $95 \%$ of the powder was $\alpha-\mathrm{Si}_{3} \mathrm{~N}_{4}$. The yttrium oxide powder was of high purity $(99.999 \%)$. Silicon nitride was added to yttrium oxide and mixed for 6 hours in propan-2-ol with alumina billets. The alumina uptake induced by grinding was 
about $0.025 \%$. The mixed powders were cold isostatically pressed at $250 \mathrm{MPa}$. The relative density was close to $54 \%$. The green moulded material was introduced into a silica container. A boron nitride diffusion barrier was necessary to prevent reactions between the capsule and the component. Degassing was carried out at $600^{\circ} \mathrm{C}$, in vacuum $\left(10^{-3} \mathrm{MPa}\right)$ for 6 hours. After sealing, the container was treated for $1 \mathrm{~h}$ at $1750^{\circ} \mathrm{C}$ and at $170 \mathrm{MPa}$ pressure.

Density measurements were carried out using Archimede principle. The microstructure was assessed by scanning electron microscopy (SEM) and transmission electron microscopy (TEM). The $\alpha / \beta$ ratio was specified by means of quantitative XRD analysis. The oxidation resistance of cubic samples was examined in a dynamic flow of oxygen $(20 \mathrm{l} / \mathrm{h})$, at atmospheric pressure, using a setaram microbalance.

\section{Results and discussion.}

Under the above conditions, more than $99 \%$ theoretical density was achieved in confirmation of previous observations $[17,18]$. The small residual porosity was obviously due to the difficulty of the elongated $\beta$-grains to rearrange: this is called the bridge effect. The specimen only contained $30 \% \alpha-\mathrm{Si}_{3} \mathrm{~N}_{4}$ and this was proof of the liquid phase role in the $\alpha-\beta$ transformation kinetics. The dissolution of the $\alpha-\mathrm{Si}_{3} \mathrm{~N}_{4}$ phase and the $\beta-\mathrm{Si}_{3} \mathrm{~N}_{4}$ reprecipitation is a function of the quantity and of the nature of the liquid phase. Due to the small amount of additive, the $\alpha-\beta$ transformation occurred mainly in the solid state at the working temperature. Figure 2a shows a homogeneous microstructure.

The aspect ratio ( $a=\Sigma l / d, l$ : maximum length, $d$ : maximum thickness) is about $9-10$, the average grain thickness is close to $0.2-0.3 \mu \mathrm{m}$. Hexagonal compact grains and elongated needle-like grains were observed by TEM. The sintered material so obtained was composed of equiaxed crystal grains, between which was a small amount of glassy phase, mainly consisting of $\mathrm{SiO}_{2}$. The thin intergranular film merging into pockets at multigrain junctions is shown in figure $2 \mathrm{~b}$. The high aspect ratio of the $\beta-\mathrm{Si}_{3} \mathrm{~N}_{4}$ grains developed in this material results in a high fracture toughness $(10.2 \mathrm{MPa} \sqrt{\mathrm{m}}$.).

In order to establish the reactivity of this silicon nitrogen ceramic, a sample was exposed to oxygen at a linear increasing temperature of $2.5^{\circ} \mathrm{C} / \mathrm{min}$. The temperature at which the reaction became noticeable was close to $1600^{\circ} \mathrm{C}$. Measurable weight gains were obtained after 24 hours oxidation at $1475{ }^{\circ} \mathrm{C}$ or higher. Isothermal curves were recorded between 1475 and $1650^{\circ} \mathrm{C}$ over 24 hours. The oxidation kinetics were parabolic. A sample exposed during 24 hours at $1590{ }^{\circ} \mathrm{C}$ shows a conversion degree $\Delta m / \Delta m_{\infty}$ of $0.02\left(\Delta m_{\infty}\right.$ : weight gain corresponding to complete oxidation).

At the beginning of reaction, an alumino-silicate film containing additives and impurities is formed. In the present study the previously observed [11] low temperature oxidation process between 800 and $1000^{\circ} \mathrm{C}$, certainly occurred but could not be detected because of the small amount of intergranular phase produced.

$\mathrm{XRD}$ analysis, with a Guinier Hagg chamber, indicated, at $1475^{\circ} \mathrm{C}$, the presence of cristobalite and of two yttrium silicates: up to $1530{ }^{\circ} \mathrm{C} \beta-\mathrm{Y}_{2} \mathrm{Si}_{2} \mathrm{O}_{7}$ and above this temperature $\gamma-\mathrm{Y}_{2} \mathrm{Si}_{2} \mathrm{O}_{7}$. The maximum $\mathrm{Y}_{2} \mathrm{Si}_{2} \mathrm{O}_{7}$ intensity was observed at $1525^{\circ} \mathrm{C}$ together also with the yttrium garnet, $\mathrm{Y}_{3} \mathrm{Al}_{5} \mathrm{O}_{12}$, which certainly constituted the intergranular crystalline phase.

At $1475{ }^{\circ} \mathrm{C}$, the surface was covered with needle like and platelet yttrium disilicate. At $1525^{\circ} \mathrm{C}$, the needle shape crystals were replaced by hexagonal grains and progressively, as temperature increased, the quantity of silica increased, such that the oxidized surface became more and more regular. The molten silica layer had flooded the yttrium silicate crystals. Due to silica enrichment, the specimen became progressively embedded in a protective scale, 

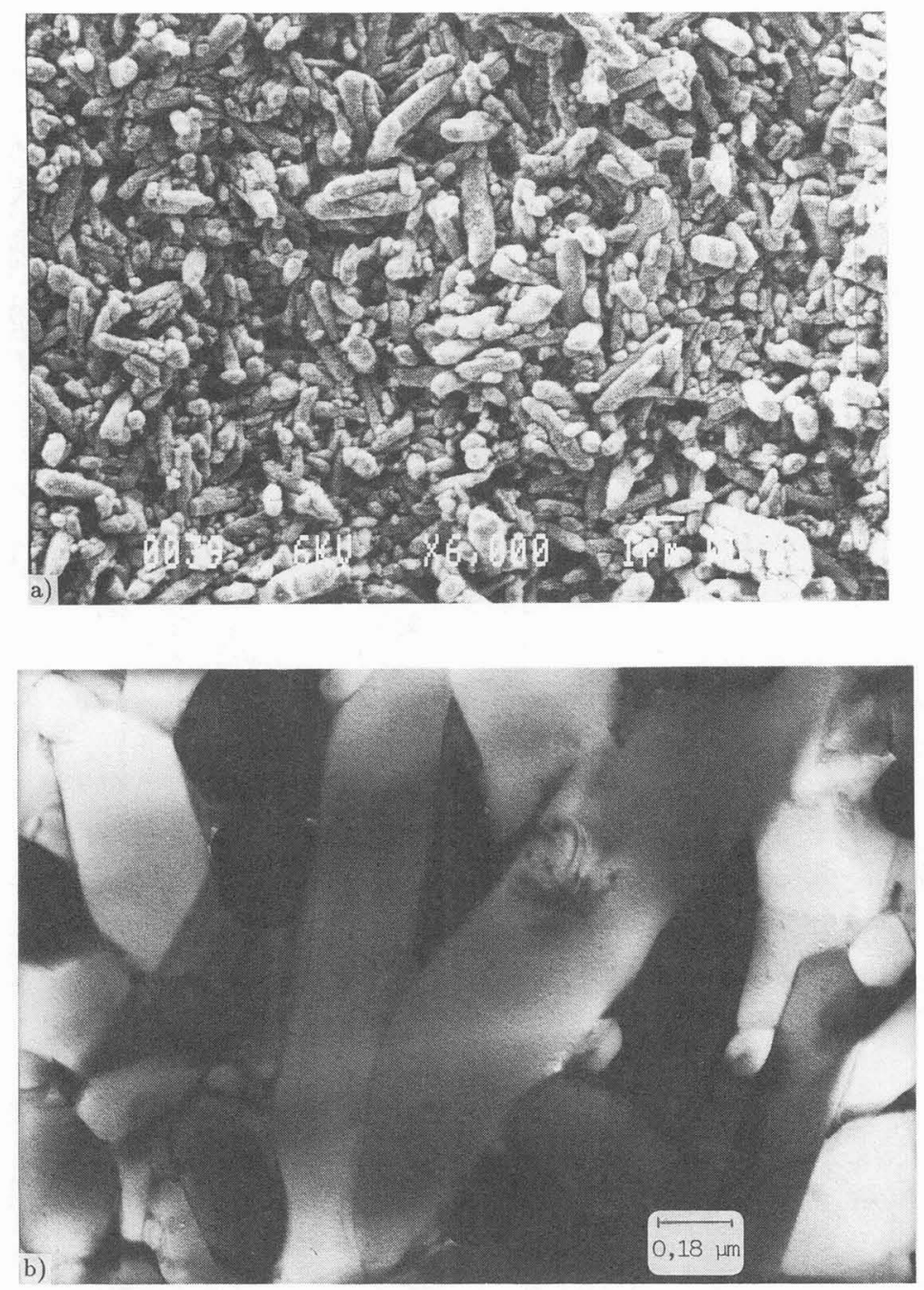

Fig. 2. - Scanning electron micrograph of an etched surface (a). Transmission electron micrograph showing small amount of glassy phase (b).

which acted as a diffusion barrier. At $1600^{\circ} \mathrm{C}$, the microcracks observed on the surface may be induced by rapid cooling. Figure 3 shows yttrium X-ray mapping of oxidized surfaces at various temperatures.

EPMA analyses of the surface crystals showed an equivalent amount of yttrium and of silicon and confirmed the presence of $\mathrm{Y}_{2} \mathrm{Si}_{2} \mathrm{O}_{7}$ up to $1575{ }^{\circ} \mathrm{C}$. At $1590^{\circ} \mathrm{C}$, no more yttrium could be detected on the surface (Fig. 4). In the same way, yttrium depletion of the bulk, coupled with an increase of the amount of this element at the internal interface, was observed by microanalysis.

Diffusion is the most probable mechanism controlling the oxidation of $\mathrm{Y}_{2} \mathrm{O}_{3}$-doped silicon nitride materials [1-4]. Cation diffusion through the grain-boundary phase to the nitrideoxide reaction interface is recognized as the probable rate-limiting step during oxidation 
a)

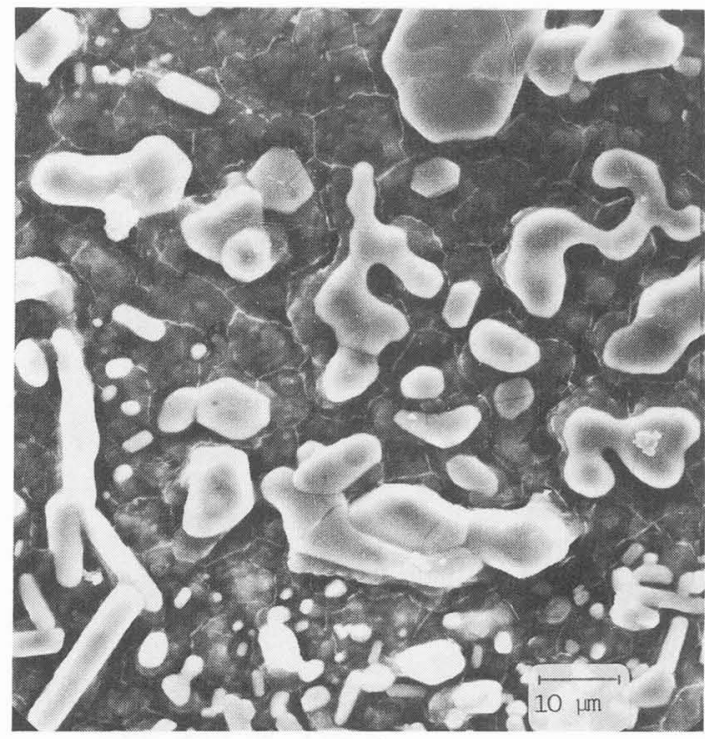

c)

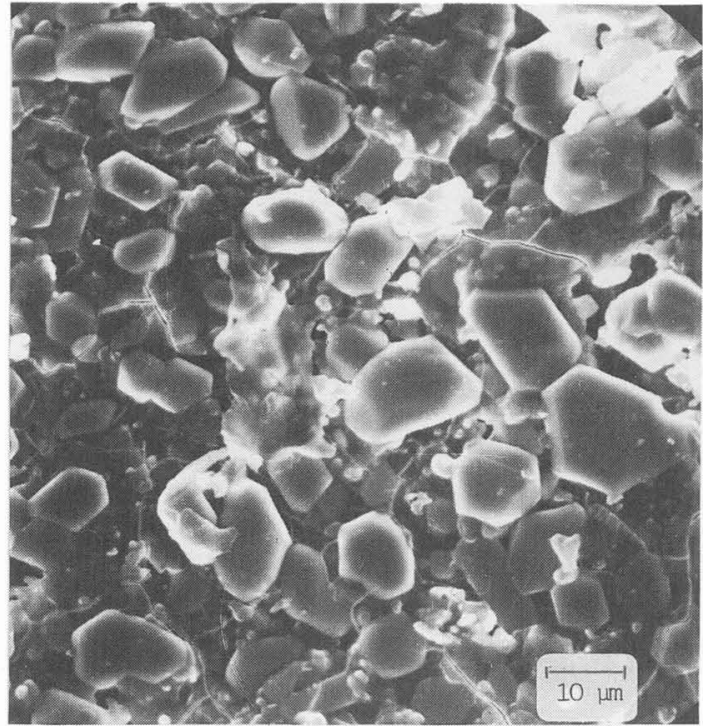

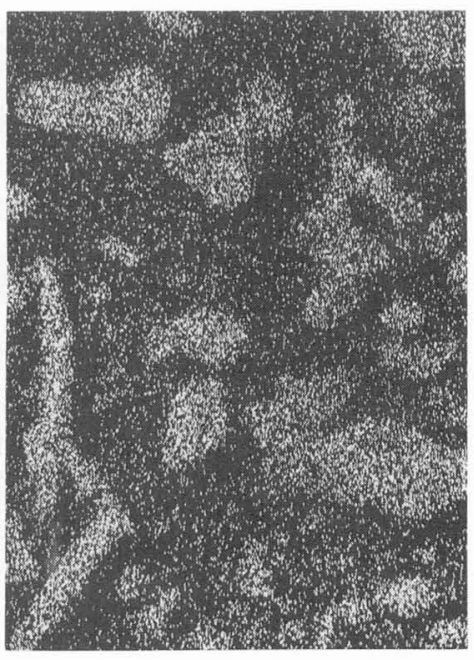

b)

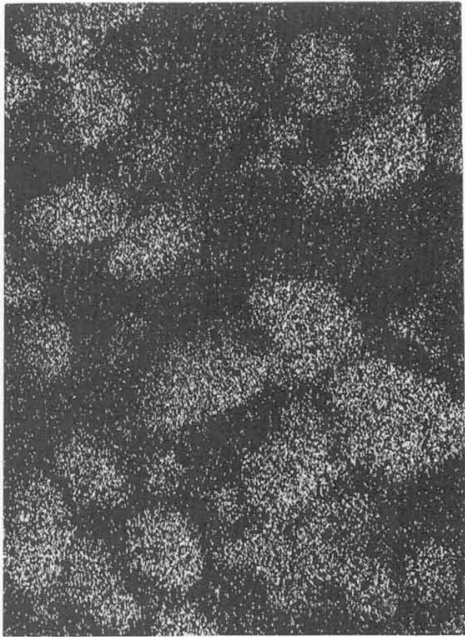

d)

Fig. 3. - a) Secondary electron image; b) Y X-ray image of surface oxidized at $1475{ }^{\circ} \mathrm{C}$; c) Secondary electron image and d) Y X-ray image of surface oxidized at $1525^{\circ} \mathrm{C}$.

at intermediate temperatures. In this study, this process occurred up to $1585{ }^{\circ} \mathrm{C}$ with an apparent activation energy of $355 \mathrm{~kJ} / \mathrm{mole}$ (Fig. 5). At $1590^{\circ} \mathrm{C}$, large nitrogen bubbles disrupt the silica film and allow oxygen to penetrate the oxide layer and permeate to the oxide-nitride interface. Above $1600^{\circ} \mathrm{C}$, the thickness of the oxide layer increases more rapidly as also does its fluidity such that diffusion of gaseous species through this scale is probably the rate controlling mechanism with an apparent activation energy value of $680 \mathrm{~kJ} / \mathrm{mole}$ (Fig. 5). 

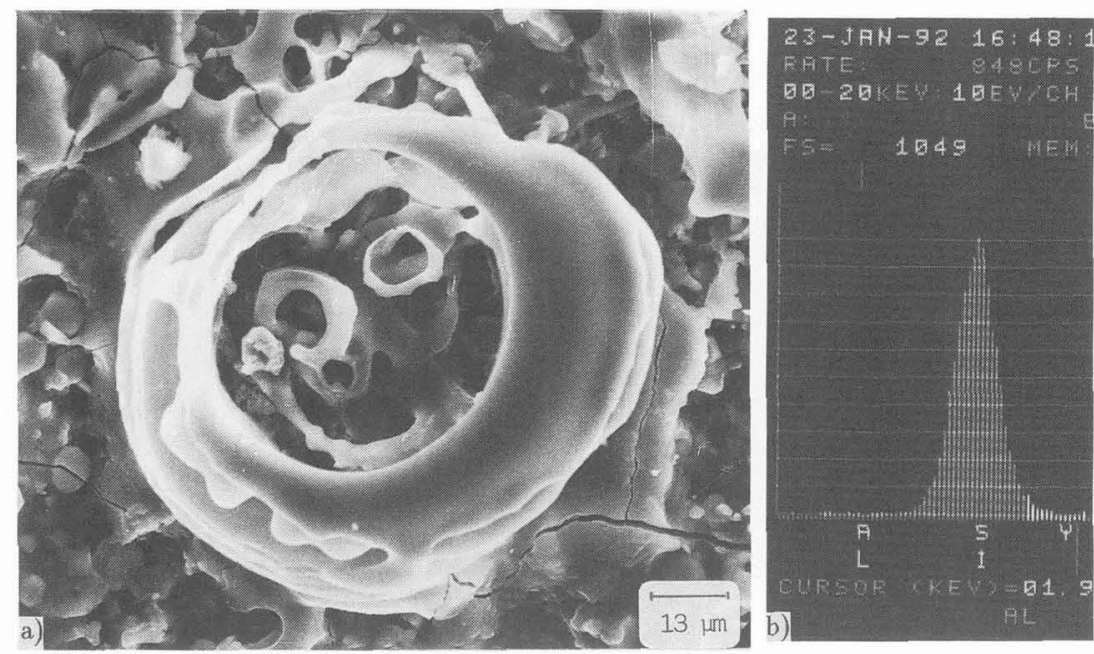

Fig. 4. - a) Secondary electron image of surface oxidized at $1590^{\circ} \mathrm{C}$ and b) EDAX analysis of surface oxide layer showing absence of yttrium.

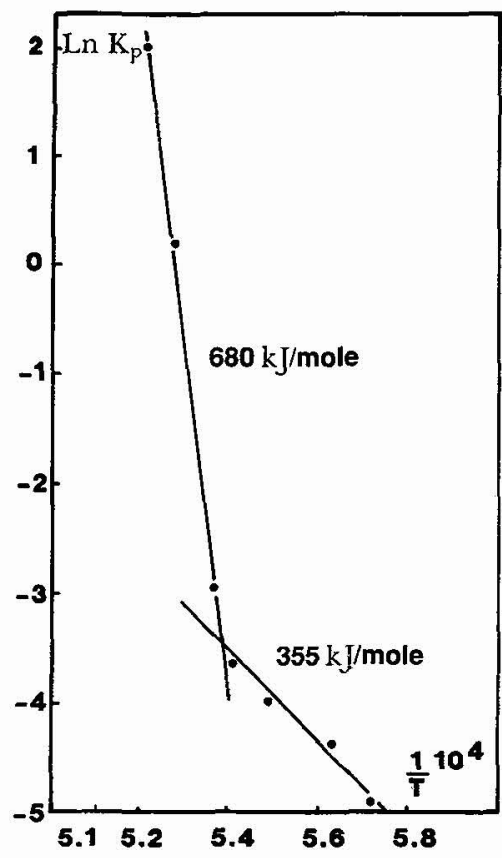

Fig. 5. - Temperature dependence of the parabolic rate constants $K_{\mathrm{p}}$.

\section{Conclusions.}

This study has confirmed the possibility of obtaining by hot isostatic pressing, a high performance silicon nitride material. The use of sub-micron silicon nitride starting powder 
favoured the densification process. In addition, minimization of the amount of an additive $\left(0.5 \mathrm{wt} \% \mathrm{Y}_{2} \mathrm{O}_{3}\right)$ required for densification at working temperature and pressure, resulted in an improvement of the oxidation behaviour up to $1585^{\circ} \mathrm{C}$. Above $1600^{\circ} \mathrm{C}$, the oxidation rate increased as the molten silica layer permitted the easy diffusion of adsorbed oxygen and of nitrogen gas released.

\section{Acknowledgements.}

The authors are grateful to Professor J. Crampon (Université de Lille) for supplying the transmission electron micrograph.

\section{References}

[1] Billy M., Desmaison J., High Temp. Tech. 4 (1986) 131.

[2] RILEY F.L., Sci. Ceram. 12 (1983) 15.

[3] Bouarroudj A., Goursat P., Besson J.L., J. Mater. Sci. 20 (1985) 1150.

[4] BABINI G.N., BELLOSI A., VINCENZINI P., ibid. 19 (1984) 1029.

[5] GazZA G.E., Am. Ceram. Soc. Bull. 54 (1975) 778.

[6] Weaver G.Q., Lucek J.W., Am. Ceram. Soc. Bull. 57 (1978) 1131.

[7] Govila R.K., Am. Ceram. Soc. Bull. 65 (1986) 1287.

[8] LANGe F.F., Singhal S.C., KuZnicki R.C., J. Am. Ceram. Soc. (1977) 249.

[9] Quackenbush C.L., Thomas Smith J., Am. Ceram. Soc. Bull. 59 (1980) 533.

[10] AMIN K.E., SiEbeIN K.N., WADE J.A., J. Mater Sci. 24 (1989) 4253.

[11] VeYret J.B., Billy M., Euro-Ceramics 1989, Vol. 3 (Elsevier Applied Science, 1989) p. 512 .

[12] Desmaison-BRUT M., Billy M., High Temperature Corrosion of Technical Ceramics (Elsevier Applied Science, 1989) p. 131.

[13] Pugach E.A., Thermochim. Acta 93 (1985) 701.

[14] Heinrich J., Bohmer M., Ceram. Forum Int. 15 (1984) 399.

[15] Echeberria J., Castro F., Euro-Ceramics 1989, Vol. 3 (Elsevier Applied Science, 1989) p. 527.

[16] Themelin L., Desmaison-brut M., Billy M., Crampon J., Ceram. Int. 18 (1992) 119.

[17] Okada H., Homma K., Fujikawa T., Kanda T., Mater. Sci. Monogr. (High Tech. Ceram.) 38A (1987) 1023.

[18] Adlerborn J., Burstrom M., Hermansson L., Larker H.T., Mater. Des. 8 (1987) 229. 